First Department of Surgery (Prof. T. OGata), Kochi Medical School, Nangokushi, Japan

\title{
A Scanning Electron Microscopic Study on the Fractured Rat Parietal Cells in Resting State and after Stimulation with Tetragastrin*
}

\author{
Wataru Osawa and Takuro Ogata
}

Received August 12, 1977

Summary. Parietal cells in the rat gastric mucosa fractured by freeze cracking methods under resting (control) state and tetragastrin stimulation were studied by field emission scanning electron microscopy. The structures thus revealed were compared with those studied by transmission electron microscopy.

In the fractured cytoplasm, intracellular canaliculi lined by numerous microvilli invaginated deeply towards the basal cytoplasm. Tubulovesicles appeared as many small holes of about $0.05 \mu$ in diameter and were distributed predominantly in the apical or pericanalicular cytoplasm. Some tubulovesicles directly opened into the secretory canaliculi. Occasionally, tiny microvilli appeared in tubulovesicles.

After being stimulated for 30 min with tetragastrin, the secretory canaliculi of parietal cells became enlarged and there was a concomitant increase in both the number and size of microvilli. Tubulovesicles also were increased in size and number and the tiny microvilli in them were also increased. The tubulovesicles were enlarged presumably as a result of membrane fusion between contiguous tubulovesicles. It was found that the enlargement of the secretory canaliculi was the result of fusion of the membrane of a single tubulovesicle or a confluence of tubulovesicles to that of the secretory canaliculus and the successive disappearance of the fused membrane.

It has been known by transmission electron microscopic (TEM) studies that parietal cells of the stomach are characterized by an extensive system of secretory canaliculi lined by microvilli, and cytoplasmic tubulovesicles which are found most frequently in the vicinity of secretory canaliculi. As close appositions of the membrane between secretory canaliculi and tubulovesicles often occurred (Iто and ScHOFIELD, 1974), tubulovesicles are more prominent in resting cells (LEESON, 1973), and canaliculi are extensive after stimulation (LEESON, 1973), the membrane flow between the two during the secretory cycle has been strongly assumed (LEEson, 1973).

Several authors have attempted to demonstrate the continuity between membranes of the canalicular system and tubulovesicles by TEM observation (SEDAR, 1961; LeEson, 1973), the freeze etch method (LeEson, 1972; Ito and Schofield, 1974) and tracer methods (Iто and SchofieLd, 1974). However, their results are still controversial and by no means conclusive. Using a scanning electron microscope (SEM), we studied and briefly reported the three-dimensional ultrastructures of freezefractured rat parietal cells (OsAwA and OGATA, 1975, 1976). In this study, we extended our study in both normal and tetragastrin stimulated animals, using a field emission type SEM and TEM, in order to demonstrate the three dimensional relationship

\footnotetext{
* This study was reported at the 7th Meeting of Japanese Clinical Electron Microscopy, September 1975 and at the Meeting of Japanese Electron Microscopy, May, 1976.
} 
among secretory canaliculi, tubulovesicles and microvilli.

\section{Materials and Methods}

Adult male Wistar rats (average 250g) were used and were fasted overnight with free access to water. As a stimulant, tetragastrin (Nihonseiyaku Co.) $125 \mu \mathrm{g} / \mathrm{kg}$ body weight was used. At the interval of 30,45 and 60 min after intraperitoneal injection of tetragastrin, rat stomachs were perfused with Ringer solution followed by $2.0 \%$ glutaraldehyde and $2.5 \%$ paraaldehyde in cacodylate buffer at $\mathrm{pH} 7.4$ through the thoracic aorta. The stomachs were later removed and fixed in the same solution for a few days. The fixed pieces of tissue immersed in $40 \%$ dimethyl sulfoxide were quench-frozen in liquid nitrogen and cracked according to the method of TokunAGA et al. (1974). They were dehydrated in alcohol series, immersed in isoamyl acetate, and dried in a critical point dryer (HCP-1) using carbon dioxide. They were then coated with gold about $20 \mathrm{~nm}$ thick in an Eiko ion coater $1 \mathrm{~B}-3$. The coated specimens were observed in a field emission type SEM (Hitachi HFS-2).

For a further comparative study by TEM, the small pieces of rat stomach fixed by perfusion were taken and refixed in $2.0 \%$ glutaraldehyde and $2.5 \%$ paraaldehyde in cacodylate buffer for $2 \mathrm{hrs}$. They were then postfixed in 1.3\% osmium tetroxide

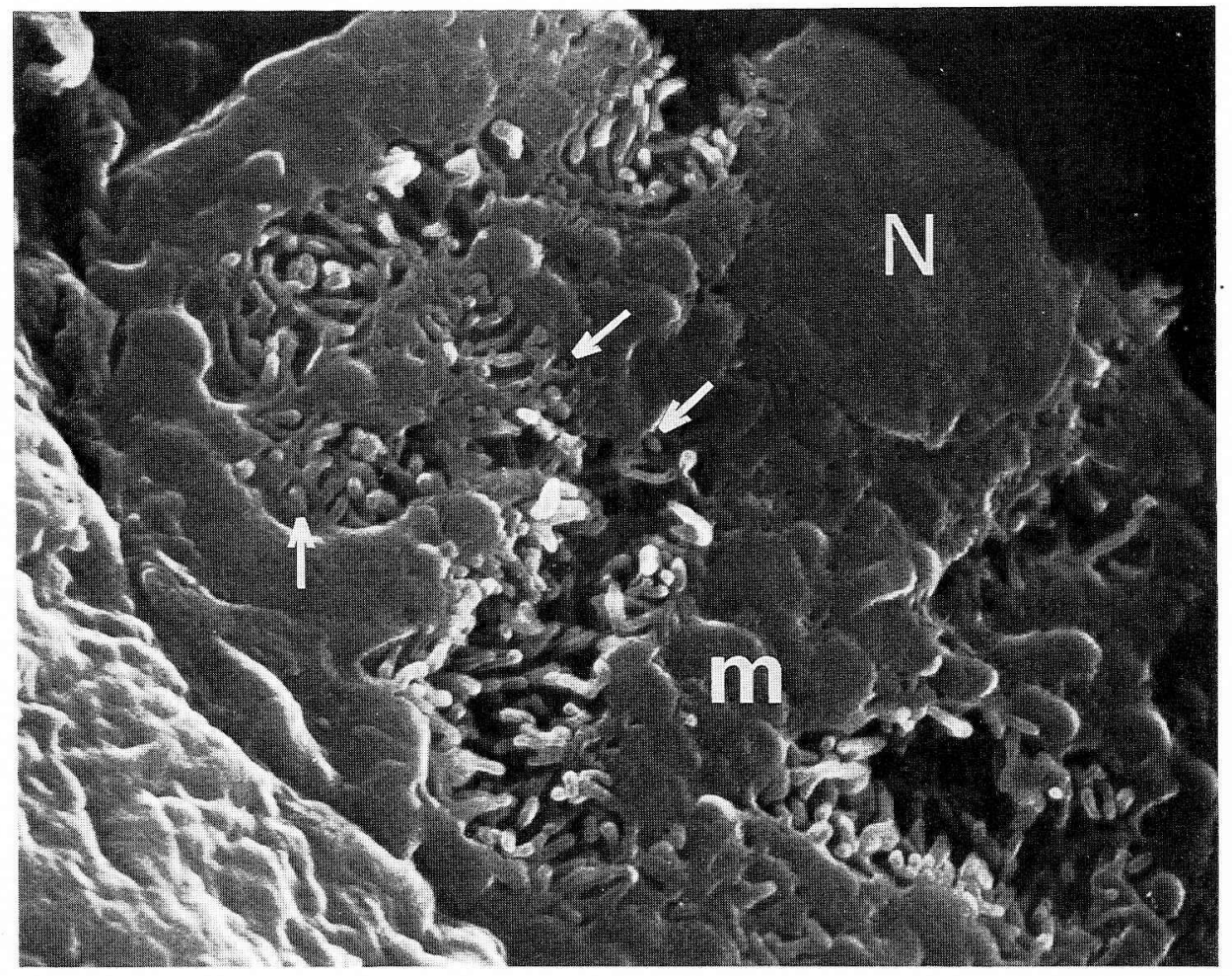

Fig. 1. Scanning electron micrograph of a fractured parietal cell of a normal rat. Note that the secretory canaliculi appear as winding furrows and caves of various sizes lined by numerous long microvilli. Arrows are small microvilli in tubulovesicles. $m$ Mitochondria, $N$ nucleus. $\times 12,000$ 
solution and embedded in Epon. Thin sections were stained with uranyl acetate, followed by lead hydroxide, and examined under a TEM (Hitachi HU-11).

\section{Results}

SEM observations on fractured parietal cells in normal or tetragastrin-stimulated rats showed some variations in the patency of the lumen of the secretory canaliculi and in the size and number of microvilli or of tubulovesicles, although their overall findings can be described as follows.

\section{Normal rat parietal cells}

In the cracked specimens of the fundic glands, parietal cells were clearly distinguished from other types of cells by their characteristic structures of the secretory canaliculi.

At lower magnification, secretory canaliculi appeared as channels lined by numerous microvilli and these varied in appearance (Fig. 1). Since

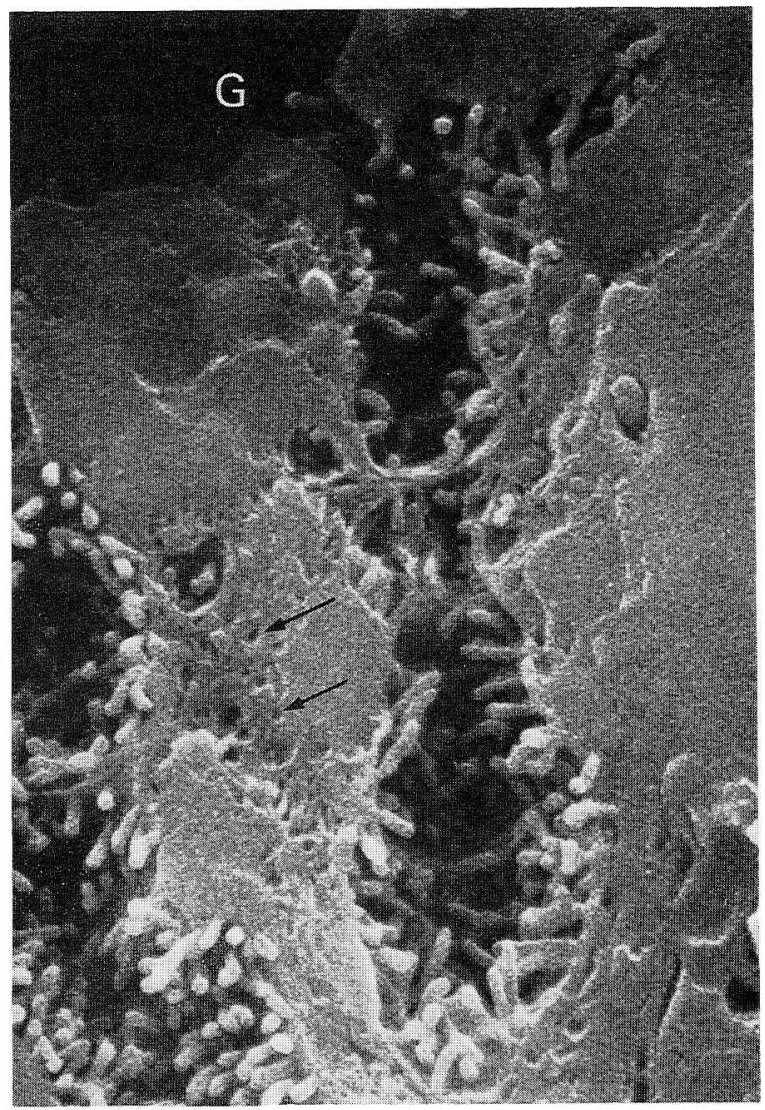

Fig. 2. A longitudinally fractured secretory canaliculus of a parietal cell in a normal rat. It extends towards the cell base and directly opens to the gland lumen $(G)$. Arrows denote tubulovesicles. $\times 14,000$ the canalicular system was branched and extended through the cytoplasm, canaliculi were fractured longitudinally, obliquely, or transversely. When longitudinally fractured, the canaliculi directly opened into the gland lumen at the cell apex (Fig. 2). Frequently, they deeply invaginated into the cytoplasm until near the cell base; they occasionally branched. A few tubulovesicles (Fig. 2, arrows) were found adjacent to the secretory canaliculi.

Transversely fractured secretory canaliculi were varied in size and in structure as seen in Figure 3. The lumen of the right lower canaliculus in Figure 3 is filled by numerous microvilli, while the central one opens widely and is lined with only a few microvilli, although both of them are connected to each other with a narrow continuity. The narrow constriction by sharp cytoplasmic projections between two canaliculi strongly suggests that both of them were separated by a septal membrane, as seen between the left upper canaliculi and the central one (Fig. 3), and recently became connected by depletion of such a septum.

The upper left canaliculi in Figure 3 is separated by membranous septa into 
various sized holes and showed a honeycomb-like structure. It is also observed that larger holes have relatively long microvilli, medium sized ones medium ones, and smaller ones shorter ones. The smallest one seen in the center of the left upper canaliculi is $0.2 \mu$ in diameter and possesses tiny microvilli with the same size and structure as the tubulovesicles with small microvilli seen in the cytoplasm (white arrow in Fig. 3). Sharp rims (arrows) observed in some tubulovesicles strongly suggest the recent depletion of septa and fusion of tubulovesicles.

Microvilli differed in shape, size and orientation, sometimes appearing bent or twisted (Fig. 1). Typically they had a club-like structure about $0.5-0.6 \mu$ in length and $0.1-0.2 \mu$ in thickness with a bulbous tip and slightly narrowed base. Most of the tops of the microvilli tended to grow up toward the direction of the orifices of

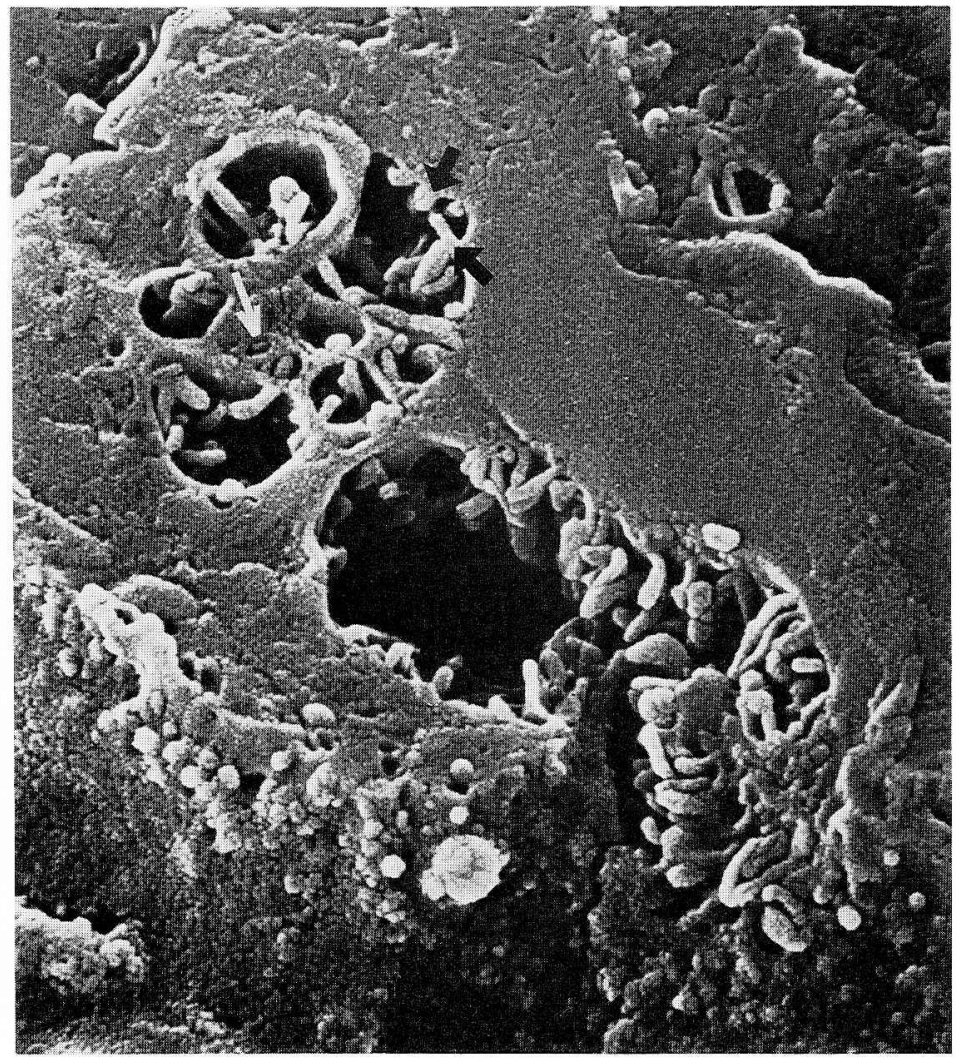

Fig. 3. Transversely fractured secretory canaliculi of a parietal cell in a normal rat. Note that the secretory canaliculi show variety in appearance. The right lower canaliculus is packed by long microvilli, while the central one opens widely and its wall is lined by a few shorter microvilli. The upper left one appears to be a honeycomb-like structure, because it is separated by membranous septa. Note that larger canaliculi have longer microvilli and smaller ones have shorter ones. The smallest one in the center (a white arrow) is $0.5 \mu$ in diameter. It has a tiny microvillus and resembles a tubulovesicle. Arrows denote sharp rims, which suggest recent depletion of fused tubulovesicular membranes. $\times 14,000$ 
the canaliculi to the gland lumen.

On the surface of the fractured cytoplasm, numerous small holes of about $0.05 \mu$ in diameter were seen (Fig. 2). Judging from the shape, size, and distribution, it was obvious that these small holes corresponded to the tubulovesicles which had been detected by TEM studies. These vesicles were distributed predominantly around the luminal and canalicular surfaces. Occasionally, fractured tubulovesicles opened directly into the secretory canaliculus (Fig. 5, arrows). Sometimes tiny microvilli appeared in tubulovesicles (Fig. 1, arrows). On the surface of the secretory canaliculi, small holes of irregular shapes were seen, apparently corresponding to the opening of the tubulovesicles (Fig. 4, arrow).

Prominent mitochondria, which were usually spherical in shape, occupied a large area

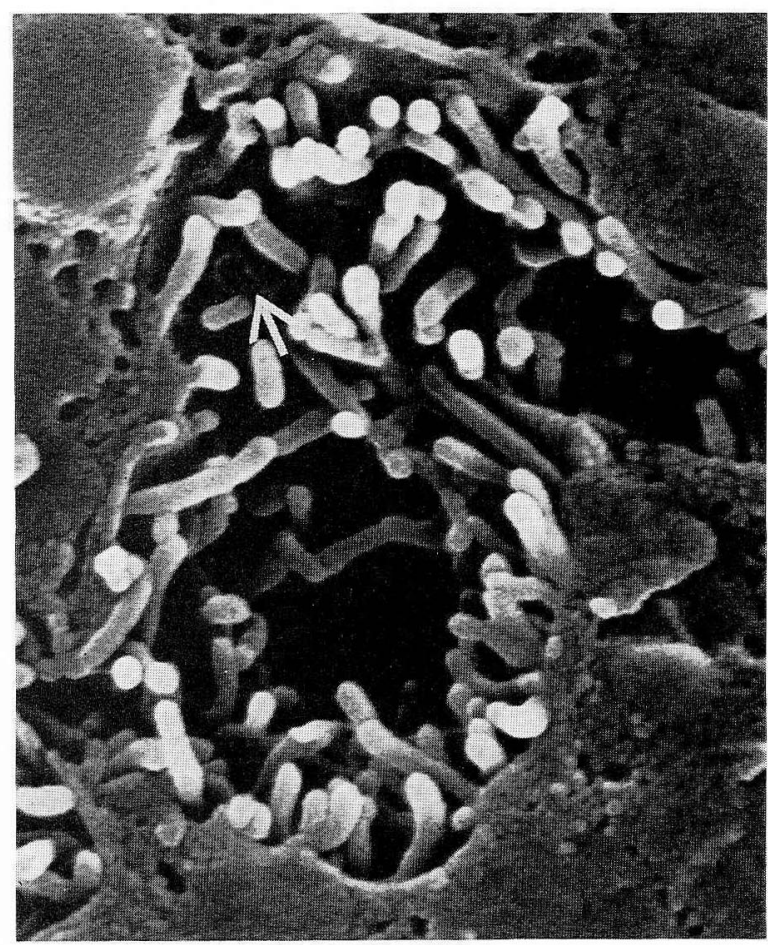

Fig. 4. Surface view of the secretory canaliculi of a parietal cell in a normal rat. Note numerous microvilli projecting towards the lumen, and small or relatively large holes (arrow), which are apparently the openings of the tubulovesicles to the secretory canaliculi. Occasionally, small microvilli occur in the tubulovesicles. $\times 28,600$ of the cytoplasm (Fig. 1). They measured about $0.6 \mu$ in diameter.

The nucleus appeared as a disk-like structure in the specimens without ionetching (Fig. 1), but in the ion-etched specimens, the nucleus appeared as a spherical form of about $4 \mu$ in diameter with nuclear holes scattered on its surface.

\section{Ultrastructural changes of parietal cells after tetragastrin stimulation}

Prominent changes were observed in the fractured parietal cells after $30 \mathrm{~min}$ with tetragastrin stimulation (Fig. 5,6). The lumen of the secretory canaliculi were generally enlarged in size, and the microvilli increased in number and in length by an average of $0.7 \mu$.

Tubulovesicles, rather evenly scattered in the cytoplasm of normal parietal cells, were prominently increased in size and number especially around the secretory canaliculi and appeared as the hollows or furrows in various sizes and forms. Direct openings of the tubulovesicles into the secretory canaliculi were occasionally seen (Fig. 5, arrows). In higher magnification, each tubulovesicle was encircled by a membrane of about $25 \mathrm{~nm}$ in thickness (Fig. 6). Close apposition of two membranes between adjacent tubulovesicles was noticed and in this possible fusion of mem- 


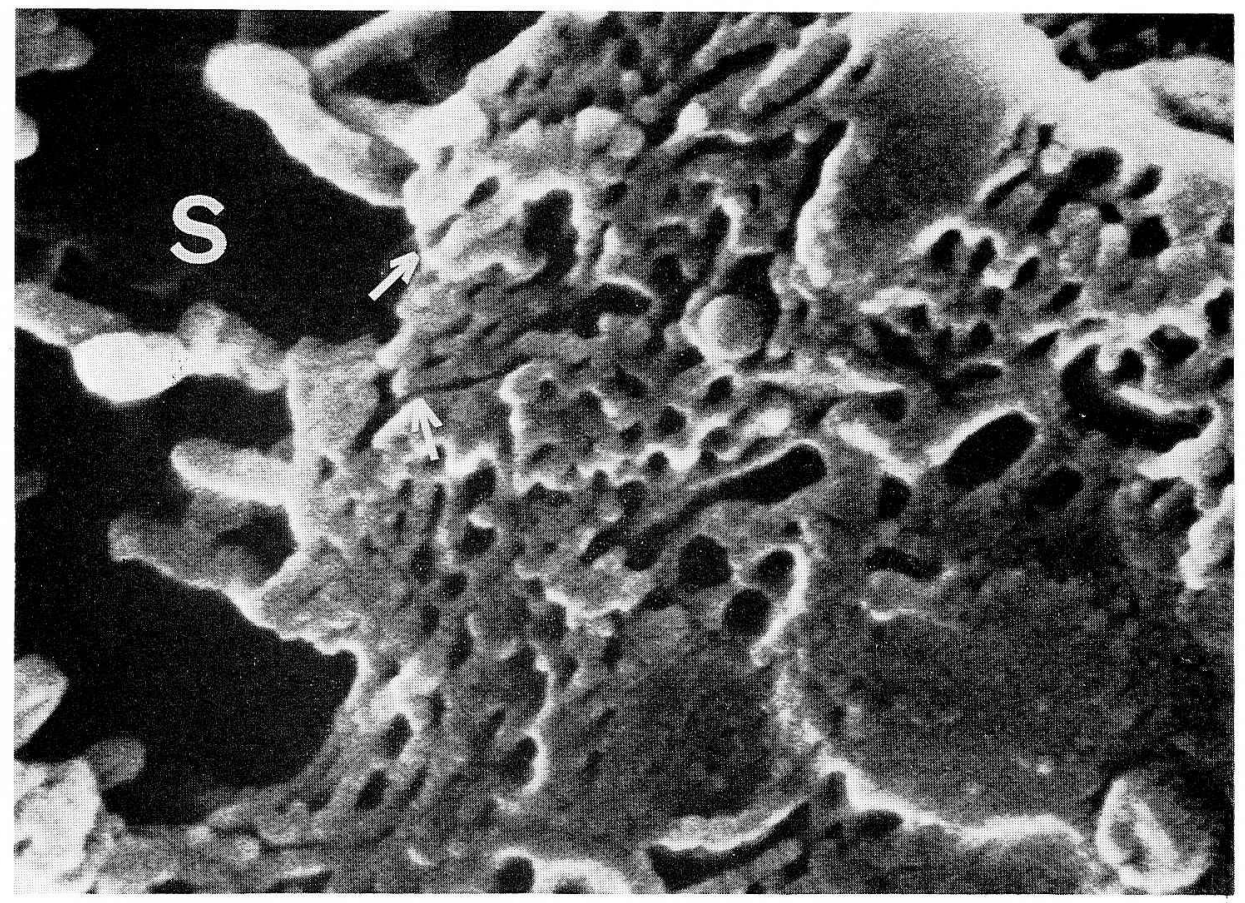

Fig. 5. Scanning electron micrograph of a fractured parietal cell $30 \mathrm{~min}$ after tetragastrin injection. Tubulovesicles appear as round or irregularly formed holes. They prominently increase in size and number as compared with those in an unstimulated parietal cell. Some tubulovesicular lumen are continuous to the secretory canaliculus lumen (arrows). Concave and convex profiles of comparatively large tubulovesicles and their sharp rims seen occasionally suggest that such large tubulovesicles are formed by the fusion of adjacent tubulovesicular membranes and successive elimination of the fused membrane. $S$ secretory canaliculi. $\times 57,000$

branes, formation of a 5-layered diaphragm, and its transformation into a 3-layered diaphragm are likely (Fig. 6), although it was difficult to evidence it, because the real surface of the membranes was covered with gold coating about $20 \mathrm{~nm}$ thick. SEM images were also obtained suggesting formation of comparatively large tubulovesicles by a detachment of a fused diaphragm and its successive rolling or shrinking (Fig. 6). Some tubulovesicles contained tiny microvilli of from $0.08-0.12 \mu$ in length. The direct continuity of membrane from the microvillous to the tubulovesicular surface was also observed (Fig. 6).

The comparative TEM study on parietal cells after 30 min treatment with tetragastrin showed that tubulovesicles were increased in size and in number especially in the pericanalicular cytoplasm (Fig. 7). Tiny microvilli appeared in some tubulovesicles (Fig. 8), and the direct continuity between the membrane of small microvilli and that of tubulovesicles was seen (Fig. 8). Graduations were observed suggesting close approximation of the membranes of adjacent tubulovesicles, fusion of these membranes, formation of a 5-layered diaphragm, progressive elimination of layers from the fused membrane, and consequently the formation of a 3-layered diaphragm, i.e., a single unit membrane (Fig. 9). The subsequent elimination of the 3-layered 


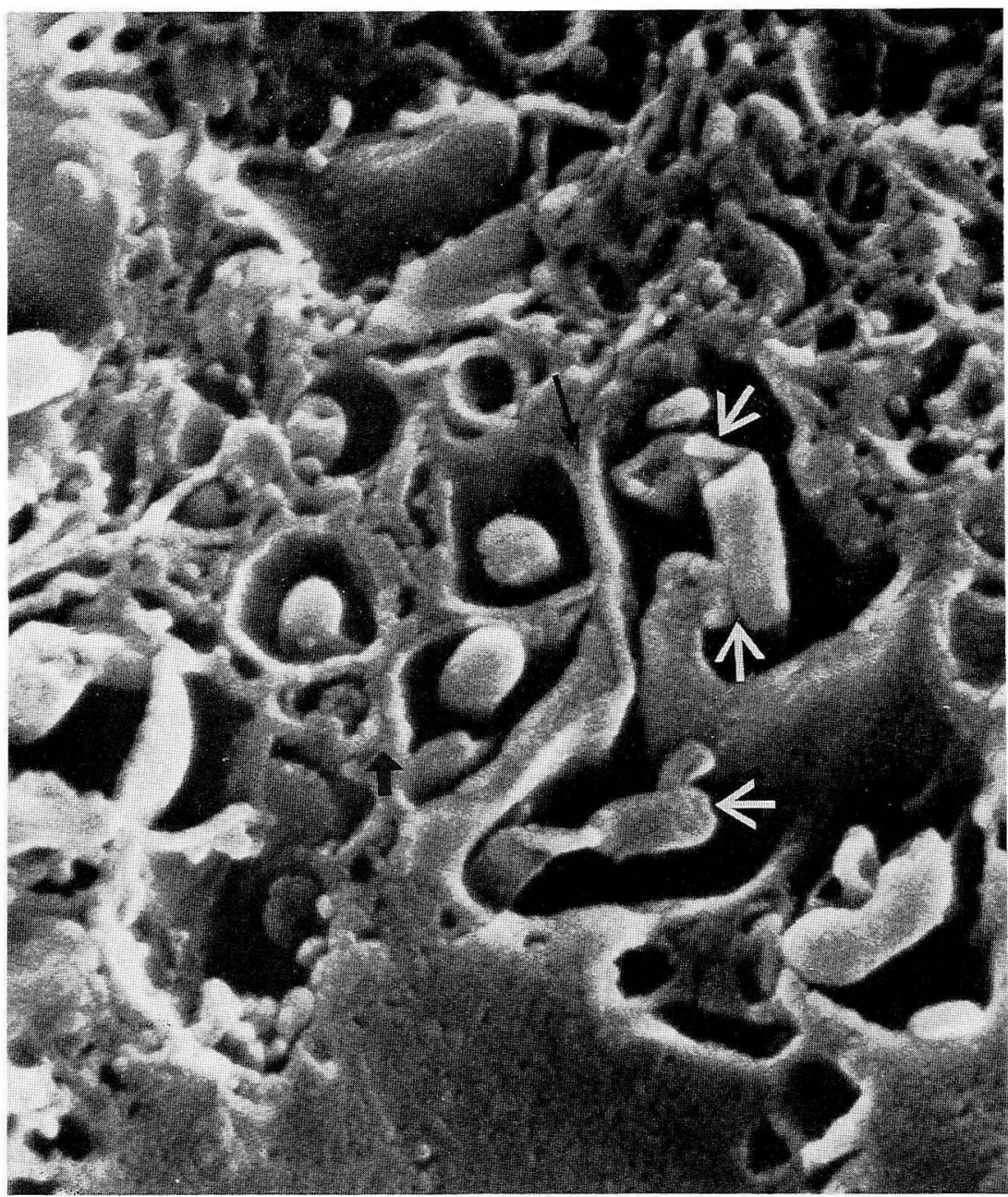

Fig. 6. High magnification of fractured tubulovesicles $30 \mathrm{~min}$ after tetragastrin stimulation. Note a marked increase of tubulovesicles and the irregularities in form and size. Small microvilli arise in some tubulovesicles. Close approximation of two adjacent membranes and structures suggesting their fusion and formation of a 5-layered diaphragm (thick arrow) and successive formation of a 3-layered diaphragm (arrow) are seen. Depletion or shrinkage of the membranes (white arrows) result in the discontinuity of smaller tubulovesicles and in successive formation of a larger tubulovesicle. $\times 51,000$

diaphragm was presumed to occur and consequently a large tubulovesicle was formed by the fusion of smaller ones. A smaller or larger tubulovesicle was apparently fused with the secretory canaliculi, and the successive disappearance of the fused membrane was also demonstrated (Fig. 10,11). These results obtained by TEM were in accordance with those observed by SEM in the rat parietal cells after tetragastrin stimulation, and summarized findings by SEM and TEM were schematically represented in Figure 13. 


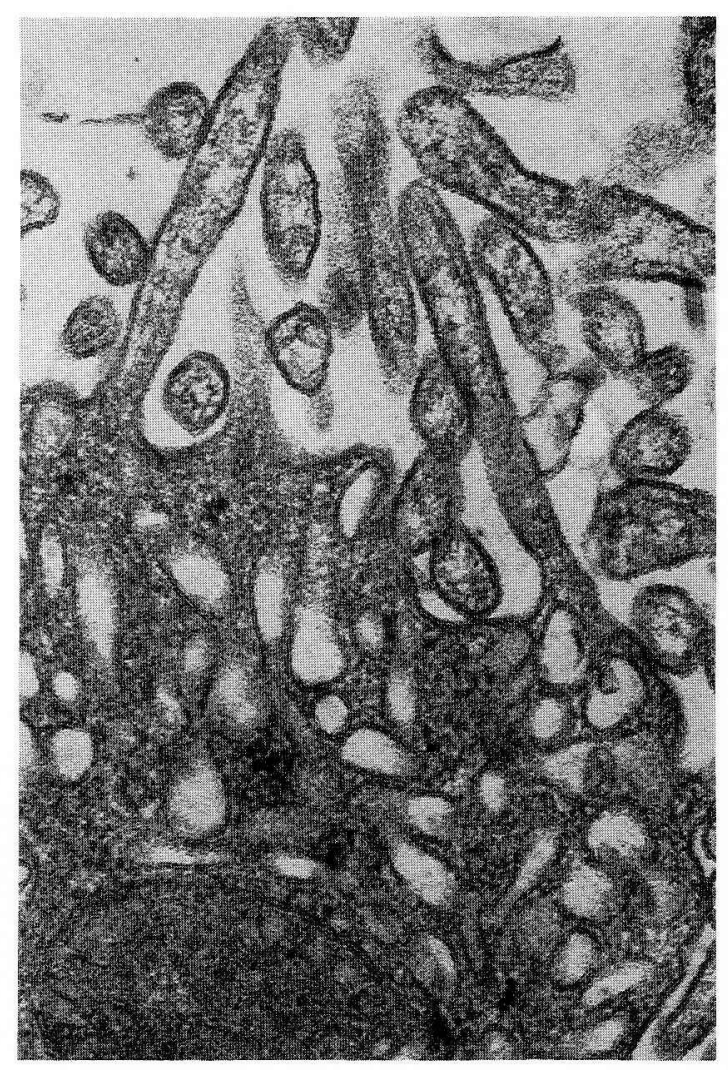

Fig. 7. Transmission electron micrograph of a parietal cell from the rat 30 min after cessation of tetragastrin injection. The intracellular canaliculus becomes enlarged and the microvilli elongated. The tubulovesicles in the cytoplasm markedly increase in size and numker. $\times 48,000$

\section{Discussion}

By the use of the freeze cracking method for the preparation of the SEM specimens reported by TANAKA (1972) or ToKUNAGA et al. (1974), the fractured surfaces of the kidney and the spleen (TokUnaga et al., 1974), the pancreas (TANAKA, 1976) and some other organs have been studied. Using the high resolution power of a field emission type SEM, this study first reports the precise three-dimensional structures of rat parietal cells, with special reference to the relationships among the tubulovesicles, microvilli, and secretory canaliculi.

The cytoplasm near the secretory canaliculus is permeated by an extensive system consisting of minute convoluted tubules which are called tubulovesicles (see ITo and Schofield, 1974; Bloom and Fawcetr, 1975). The relationship of the tubulovesicles to the secretory canaliculi has still been unclear, and their significance in the secretory function of the cell is controversial.

By TEM observation of human gastric biopsies, Frexinos et al. (1971) reported that, after stimulation by gastrin, the microvilli and plasmalemmae of the apical and canalicular surface were markedly increased, whereas tubulovesicles were decreased. HeLander and Hirshowitz (1972) and Leeson (1973) suggested that the area occupied by plasma membrane was increased by exteriorization of the tubulovesicu- 
Fig. 8. Transmission electron micrograph of a parietal cell $30 \mathrm{~min}$ after tetragastrin injection. Tubulovesicles appear as vesicles or vacuoles. Note the two tiny microvilli growing up in an enlarged tubulovesicle. The membrane continuity between a tubulovesicle and a tiny microvillus is seen. $\times 100,000$
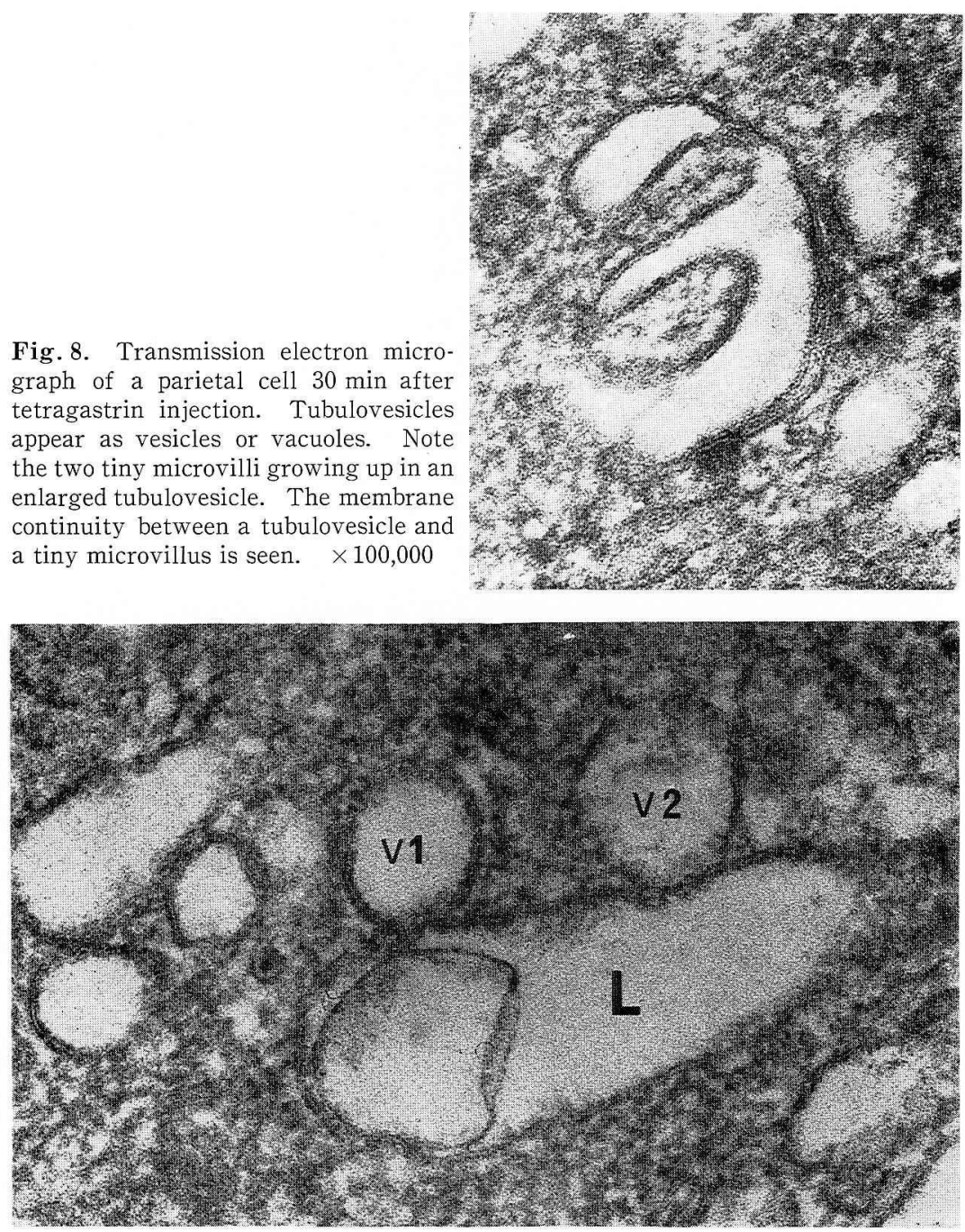

Fig. 9. A parietal cell 30 min after tetragastrin injection. The membranes of two tubulovesicle (V1 and V2) are under fusion with the membrane of an enlarged tubulovesicle $(L)$. In $V 1$, the fusion appears to produce a 5-layered diaphragm. However, the diaphragm in V2 is possibly 3-layered due to the progressive elimination after fusion. $\times 135,000$

lar membrane by membrane flow or exchange and that continuity was established between the lumen of tubulovesicles and the extracellular lumen. From a freezeetch study, LEESON (1972) reported on a reversal of the membrane face of tubulovesicles compared to those of microvilli, that is, the A-membrane was on the concave profiles of tubulovesicles but on the convex profiles of microvilli. Furthermore, he stated that the tubulovesicles are of plasma membrane origin and that the entire membrane surface of microvilli of the canaliculi and of the tubulovesicles provides an extensive surface for ion-exchange. 


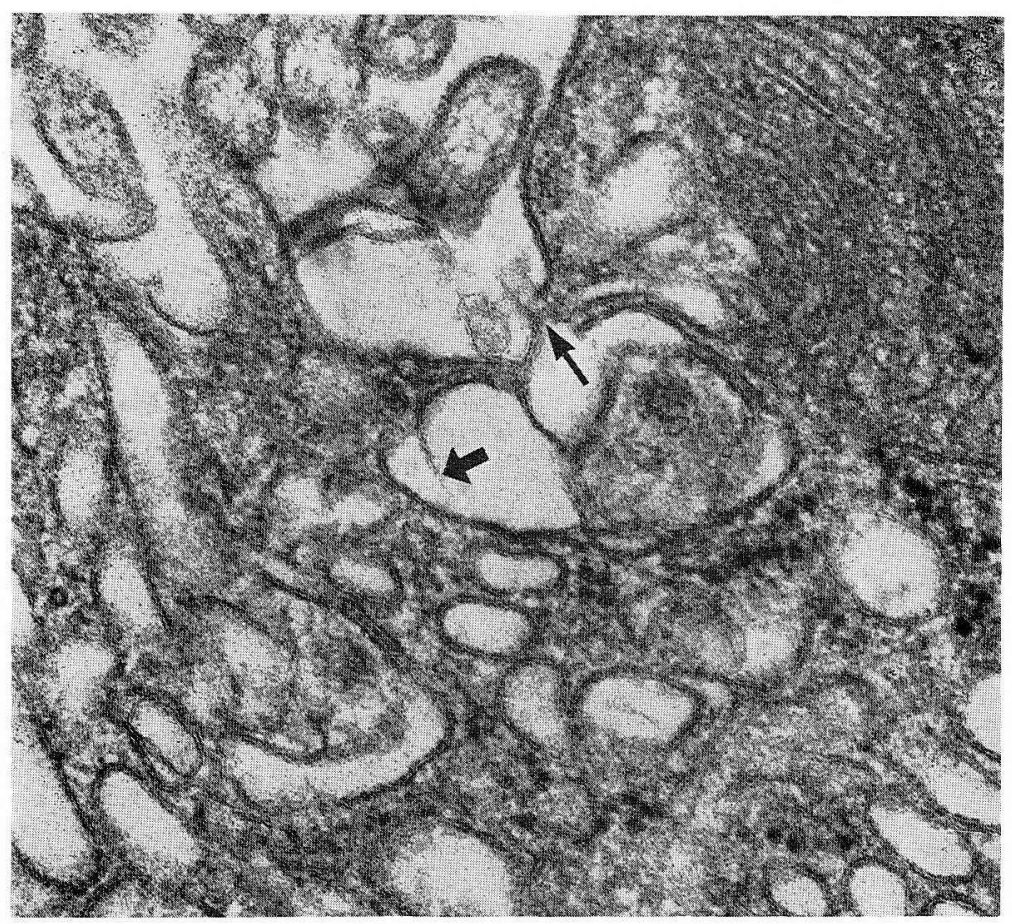

Fig. 10. A parietal cell 30 min after tetragastrin injection. Cluster of tubulovesicles located in the cytoplasm around the secretory canaliculi. A part of the tubulovesicular membrane fuses with the membrane of a secretory canalicule and successive elimination is seen (arrow). A thick arrow shows the depletion of a fused membrane. $\times 76,000$

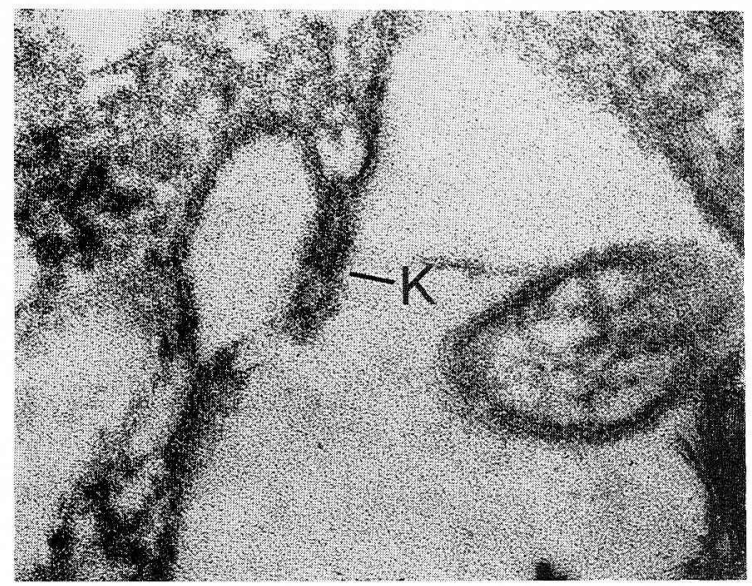

Fig. 11. A parietal cell 30 min after tetragastrin injection. A tubulovesicle adjacent to the secretory canaliculus opens on the secretory canaliculus, probably by elimination of fused membrane between the secretory canaliculus and the tubulovesicle. Note that the diaphragm is provided with a central knob $(K) . \quad \times 150,000$

More recently Ito and Schofield (1974) clearly demonstrated a depletion of the cytoplasmic tubulovesicular membrane and a concomitant increase in the size and number of microvilli in parietal cells of mice stimulated by secretagogous drugs 
or hormones, but could not find a continuity of the secretory canaliculus membrane and the cytoplasmic tubular system by the use of lanthanum or peroxidase trace techniques and freeze-fracture replicas. ITo and ScHofIELD (1974) stressed that from the previous studies there was as yet no convincing evidence that such a process occurs in parietal cells.

From the present observations by SEM, the continuity between the lumen of secretory canaliculi and that of the tubulovesicles seem most likely. Occurrence of small microvilli was demonstrated in the latter. Thirty minutes after tetragastrin stimulation the tubulovesicles increased in size and in number, and the small microvilli were more frequently found (Fig. 5, 6). Furthermore, the high resolution power of field emission type SEM enabled us to observe the three-dimensional structure of the tubulovesicular membrane and to presume the possible mechanism of membrane migration after tetragastrin stimulation. Probable fusion and depletion of membranes was thus demonstrable in this study, although the membranes in question were conspicuously thicker (about $25 \mathrm{~nm}$ ) than appearing under the TEM $(5-7 \mathrm{~nm}$, DeRobertis et al., 1975).

PALADE and BRUNS (1968) reported the fusion of the vesicular membrane with plasmalemma and the successive elimination of the layer of the two fused membranes in vascular endothelia. In the present study, the mutual fusion of tubulovesicular membranes or the fusion of the tubulovesicular membrane to the secretory

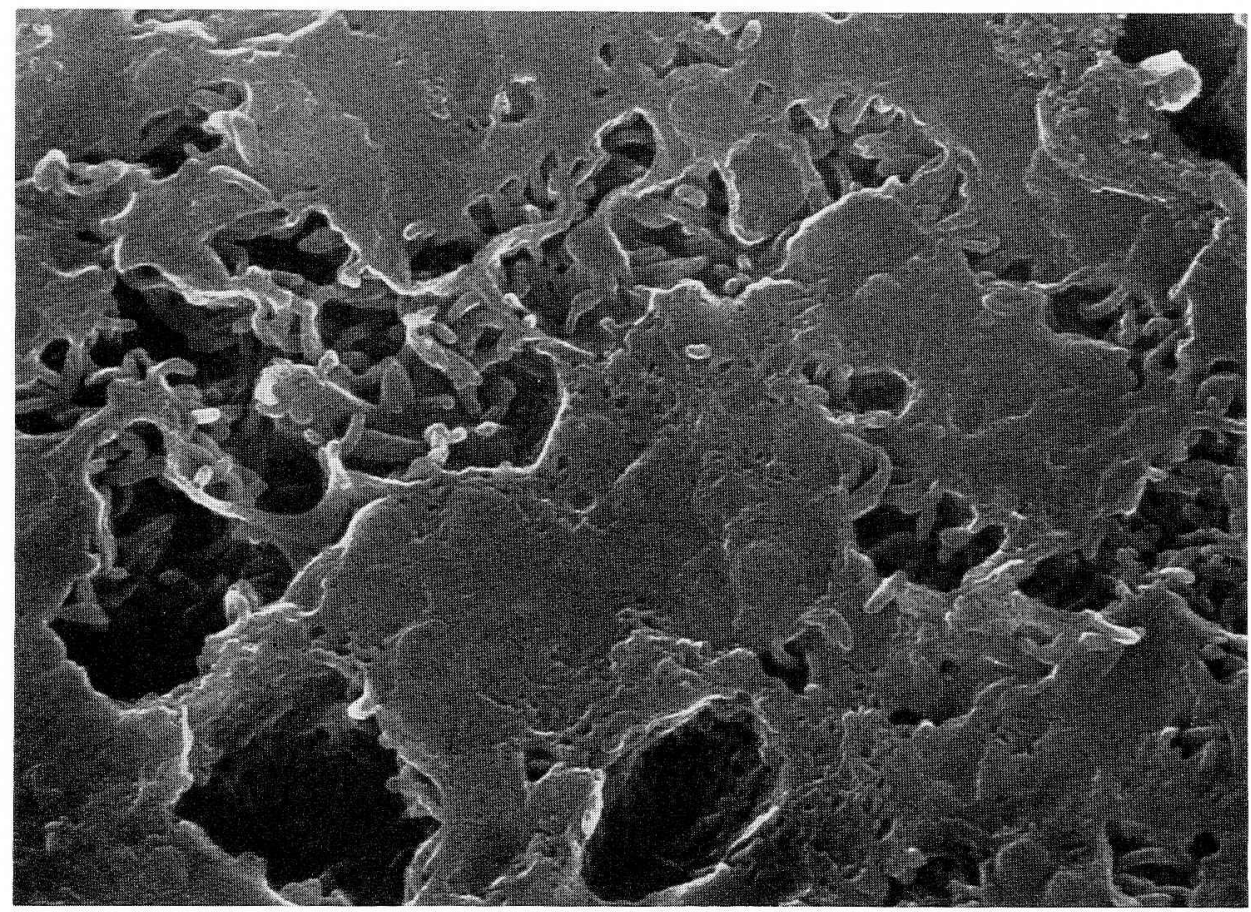

Fig. 12. A fractured parietal cell from the stimulated rat $60 \mathrm{~min}$ after tetragastrin injection. Note that tubulovesicles prominently decrease in size and number. The secretory canaliculi become widely open and the microvilli less in number and shorter in size. In some secretory canaliculi, microvilli have almost disappeared. $\times 9,600$ 
canaliculus membrane and the successive elimination of the fused membrane were apparent under both SEM and TEM, especially 30 min after tetragastrin stimulation.

In higher magnification of SEM and in concomitant observations of TEM in parietal cells after 30 min with tetragastrin stimulation, a close approximation of the membranes between adjacent tubulovesicles was demonstrated. Images would be obtained which suggested the process that a 5 -layered diaphragm was formed by the fusion of the membranes and changed to a 3-layered diaphragm as the result of the successive elimination of the fused 5-layered diaphragm, a process proposed by PALADE and BRUNS (1968). In a similar procedure, the membrane of a tubulovesicle apparently fused to that of the secretory canaliculi, and then the depletion of the fused membrane seemed to occur. Tubulovesicles were thus believed to open into the secretory canaliculi and to contribute to the formation of new microvilli.

ITo and SchofIELD (1974) also pointed out that lanthanum, when used as the tracer, was readily demonstrated between the microvilli and filling the extracellular cleft between the basal and lateral folds, but did not penetrate into the tubulovesicular system. This finding, which is controversial to the present result of the connection of the tubulovesicle to the secretory canaliculi seems to be accounted for by the following possibility. The penetration of lanthanum into the tubulovesicles, under membrane fusion with the secretory canaliculi must be intercepted by the still
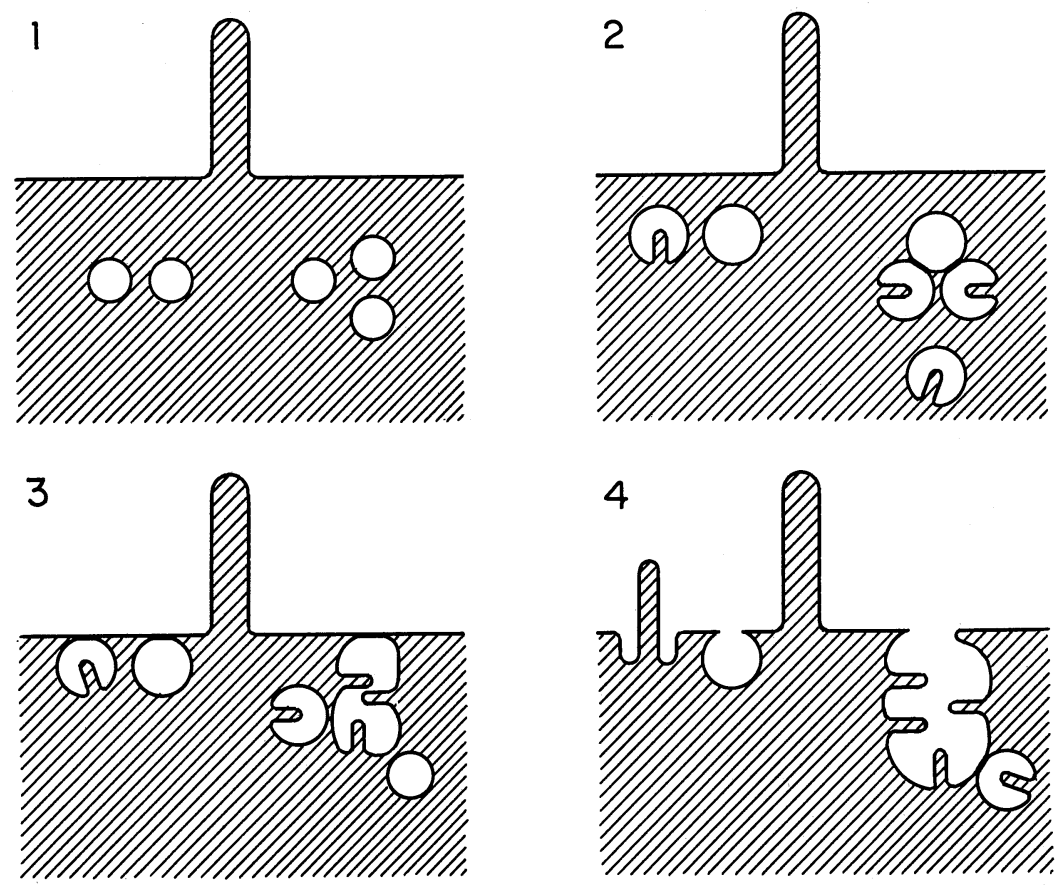

Fig. 13. Schematic representation of the possible sequence which takes place in the parietal cells after tetragastrin stimulation. On the left side of the microvillus is shown the procedure in which a single tubulovesicle directly fuses to the secretory canaliculus, and on the right side the procedure in which a large tubulovesicle, formed by successive fusions of smaller tubulovesicles, fuses to the secretory canaliculus. 
remaining membranes. After the depletion of fused membranes, lanthanum does penetrate into the tubulovesicles, but such tubulovesicular lumens might be regarded as a part of the secretory canaliculi and not counted as the lumens of the tubulovesicles.

The present SEM observation first demonstrated the occurrence of small microvilli in tubulovesicles. They are sporadical in the resting state and are increased in number in the stimulated state.

RuBin et al. (1968) reported that tubulovesicles of human parietal cells contained small particles, which had a density similar to that of the cytoplasmic matrix and were surrounded by a unit membrane. They also described that occasionally a portion of surrounding cytoplasm extended into the vesicles, and that frequently vesicles had apparently free particles suggesting that they do not merely represent sections through such projections.

The present SEM observation revealed that the membranes of the tiny microvilli are directly continued to the tubulovesicle membrane (Fig. 6). In TEM observation, the appearance of longitudinally-sectioned small microvilli were occasionally seen in tubulovesicles (Fig. 8). In some tubulovesicles, small particles surrounded by a unit membrane as described by RUBIN et al. (1968) were also seen. These particles probably correspond to a cross section of small microvilli, because their size, content and membrane thickness are closely similar to those of the longitudinally-cut small microvilli.

The exact significance of the appearance of small microvilli in tubulovesicles and their transformation to the long microvilli in the secretory canaliculi is unknown, but possibly by this mechanism, some amount of the membrane of tubulovesicles was transformed to the membrane of the microvilli in the secretory canaliculi. Consequently, the membrane of the tubulovesicles would be preserved as the membrane of the secretory canaliculi, although some of them are believed to disappear in the process of the depletion of fused membrane. Possibly after cessation of acid secretion, the microvilli membrane would be retrieved to the tubulovesicles, but further investigation would be necessary to demonstrate this process.

ITo and SchofIELD (1974) described that $1 \mathrm{hr}$ after pentagastrin injection, cytoplasmic tubules of mouse parietal cells were either completely or almost completely depleted, and the secretory canaliculi were usually occluded by markedly elongated microvilli. In this study, the increase of tubulovesicles was observed after $30 \mathrm{~min}$ of tetragastrin stimulation. Probably, this difference was mainly attributable to the time difference after stimulation, because 45 or $60 \mathrm{~min}$ after tetragastrin stimulation the tubulovesicles were markedly decreased also in our study (Fig. 12).

In this study, the membrane fusion between tubulovesicles and secretory canaliculi and the successive elimination of this fused membrane were proposed. If the tubulovesicles contain hydrochloric acid, the secretion of hydrochloric acid into the secretory canaliculi might occur by this mechanism. If this hypothesis is valid, the mechanism of hydrochloric acid release will show the same exocytotic pattern as the release of protein secretions like zymogen granules in the pancreatic acinar cells. Studies to determine the nature of the content of the tubulovesicles will be necessary to confirm this hypothesis. 


\section{正常およびテトラガストリン刺激後のラット壁細胞の 走査電子顕微鏡による研究}

$$
\text { 大沢亘と緒方 卓 郎 }
$$

ラットの正常およびテトラガストリン刺激後の胃体部粘膜を凍結割断し，壁細胞の立体 的超微細構造電界放射型走査電顕により観察し，透過電顕所見とも対比検討した。

壁細胞の割断像では，多数の微絨毛を有する細胞内分泌細管が胞体内に深く湾入し，そ の出口ほ胃腺腔と連結している。一方胞体内 とくに細胞内分泌細管の周辺には，直径約 $0.05 \mu$ の tubulovesicle に一致する小孔が多数みられ，ときにこの中に小微䋐毛がみられ る.また直径 約 $0.6 \mu$ の球形の 多数の糸粒体の堆積がみられる.

テトラガストリン刺激後 30 分では，tubulovesicle は増大し，その中に出現する小さい 微絨毛の頻度も増す。また 細胞内分泌細管へ tubulovesicle が開口している像も増す. また隣接した tubulovesicle どうしの近接，膜どうしの融合，消失がみられ，その結果 大きな tubulovesicle が形成される。一方 単独の tubulovesicle の膜, あるいは融合して 大きくなつた tubulovesicle の膜が，細胞内分泌細管の膜と融合，消失し，その結果，刺 激時の細胞内分泌細管が増大するととが明らかとなつた。

\section{References}

Bloom, W. and D. W. Fawcett : A textbook of histology. 10th ed., W. B. Saunders, PhiladelphiaLondon-Toronto, 1975.

DeRobertis, E. D. P., F. A. Saez and E. M. F. DeRobertis, Jr.: Cell biology. 6th ed., W. B. Saunders, Philadelphia-London-Toronto, 1975.

Frexinos, J., M. Carballido, A. Louis and A. Ribet: Effects of pentagastrin stimulation on human parietal cells. An electron microscopic structures. Amer. J. Dig. Dis. 16: 1065-1074 (1971).

Helander, H. F. and B. I. Hirschowitz : Quantitative ultrastructural studies of gastric parietal cells. Gastroenterology 6: 951-961 (1972).

Ito, S. and G. C. Schofield : Studies on the depletion and accumulation of microvilli and changes in the tubulovesicular compartment of mouse parietal cells in relation to gastric acid secretion. J. Cell Biol. 63: 364-382 (1974).

Leeson, T. S.: Parietal cell canaliculi: a freeze-etch study. Cytobiologie 5: 352-362 (1972). : Canaliculi and tubulovesicles of rat parietal cells (1). Amer. J. Anat. 136: 541-547 (1973).

Osawa, W. and T. Ogata : A scanning electron microscopic observation of the intracellular structure of the fundic gland cells of the rat stomach. J. clin. Electron Microsc. 8: 5-6 (1975).

the fundic gland cells of the rat stomach (Abst.). J. Electron Microsc. 25: 211 (1976).

Palade, G. E. and R. B. Bruns : Structural modulations of plasmalemmal vesicles. J. Cell Biol. 37: 633-649 (1968).

Rubin, W., L. L. Ross, M. H. Sleisenger and G. H. Jeffries: The normal human gastric epithelia. Lab. Invest. 6: 598-626 (1968). 
Sedar, A. W. and M. H. F. Friedman : Correlation of the fine structure of the gastric parietal cell (dog) with functional activity of the stomach. J. biophys. biochem. Cytol. 11: 349-363 (1961).

Tanaka, K.: Freezed resin cracking method for scanning electron microscopy of biological materials. Naturwissenschaften 59: 77 (1972).

Tanaka, K., A. Iino and T. Naguro: Scanning electron microscopic observation on intracellular structures of ion-etched materials. Arch. histol. jap. 39: 165-175 (1976).

Tokunaga, J., M. Edanaga, T. Fujita and K. Adachi : Freeze cracking of scanning electron microscopic specimens. A study of the kidney and spleen. Arch. histol. jap. 37: 165-182 (1974).

大 沢 亘
干781-51 南国市岡豊町小蓮
高知医科大学
第一外科学教室
Dr. Wataru Osawa

First Department of Surgery

Kochi Medical School

Nangoku-shi

781-51 Japan 